\title{
In the Classroom
}

\section{Creating Multimodal Reflections in an IEP Speaking-Listening Course}

Cynthia J. Macknish

Reflection is a crucial element in service-learning and having English as a second language (ESL) students create multimodal reflections on their service-learning experience helps them develop multiliteracies and results in learning that is authentic and meaningful as students engage in social discourse while they develop their academic language and digital skills. Research indicates that integrating multimodal projects in ESL courses has the capacity to promote collaboration and learner autonomy, and improve motivation, self-confidence, and language skills. That said, the purpose for integrating multimodality should be clear, and explicit teaching, scaffolding, monitoring, and feedback are necessary for success. In addition, there are challenges to address. In this article, procedures for creating multimodal reflections using Adobe Spark are explained with reference to learners in an Intensive English Program (IEP) service-learning context, and suggestions are shared on how teachers of all levels can adopt and modify the project for different contexts. Challenges are discussed and assessment tools are presented.

La réflexion étant un élément essentiel du domaine de l'apprentissage par l'expérience axé sur la communauté, il est important que les apprenantes et apprenants d'anglais langue seconde (ESL) créent des réflexions multimodales sur leur expérience d'apprentissage par l'expérience pour les aider à développer des littératies multiples et à acquérir des connaissances authentiques et significatives au moment où ils se socialisent en développant leur expression académique et leurs compétences numériques. Les recherches indiquent que l'intégration de projets multimodaux dans les cours d'anglais langue seconde a le pouvoir de favoriser la collaboration et l'autonomie des apprenantes et apprenants en plus d'en améliorer la motivation, la confiance en soi et les compétences linguistiques. Cela dit, l'objectif de l'intégration de l'intermodalité doit être clairement établi, et le succès de l'entreprise dépendra du caractère explicite de l'enseignement, de l'échafaudage, du suivi et de la rétroaction. Qui plus est, il y a des défis à relever. Dans le présent article, les procédures liées à la création de réflexions multimodales à l'aide d'Adobe Spark sont expliquées en lien avec les apprenantes et apprenants dans un contexte d'apprentissage par l'expérience dans le cadre d'un programme intensif d'anglais (IEP), et des suggestions sont partagées sur la manière dont les enseignantes et enseignants de tous les niveaux peuvent adopter et modifier 
le projet afin de l'adapter à divers contextes. Des défis sont discutés et des outils d'évaluation sont présentés.

KEYWORDS: multimodality, service learning, IEP (Intensive English Program)

\section{Introduction}

This article demonstrates the significance of service-learning and multimodalities in English as a second language (ESL) teaching and learning, which are relevant directions in the 21st century. Service-learning is "a teaching and learning strategy integrating meaningful community engagement with instruction and reflection to enrich the learning experience, teach civic responsibility, and strengthen communities" (National Service Learning Clearinghouse, in Ryan, 2012, p. 4). Reflection is a crucial element in servicelearning and having ESL students create multimodal reflections on their service-learning experience helps them develop multiliteracies and results in learning that is authentic and meaningful as students engage in social discourse while they develop academic language and digital literacy.

\section{Theoretical Grounding}

The words, "Let your students create" (Prensky, 2010, p. 149) inspired my use of technology in a speaking and listening course in an Intensive English Program (IEP). Rather than replacing old methods with technology, I broadened them to allow a greater range of skill development and motivation by using digital tools. Typically, speaking-listening courses might include in-class oral presentations requiring students to demonstrate the use of learned language and presentation skills, such as eye contact, use of voice and gestures. Classmates listen, ask questions, and sometimes conduct peer evaluations of the presentations based on set criteria discussed in advance. Undeniably, such live presentations can be valuable in helping students develop confidence speaking in front of, and interacting spontaneously with, an audience. The peer assessments help develop critical thinking skills and metacognition. While live presentations are important, the use of technology can help students improve their skills further.

Providing opportunities to create multimodal presentations enables students to expand their communication skills beyond the linguistic to include visual, spatial, audio, and gestural modes, that is, being literate in multimodalities. Spires and Bartlett (2012) stress the importance of this, suggesting that individuals are not literate unless they are able to consume and produce both written and digital texts. The need to help students use and design multimodal texts and navigate culturally and linguistically diverse discourses has been part of the New London Group's (NLG, 1996) multiliteracies pedagogy for more than two decades. Multiliteracies pedagogy helps students 
develop critical awareness of how a range of modes in new text types (multimodal) come together to form new ways of communicating. This pedagogy, originally structured around four dimensions: situated practice, overt instruction, critical framing, and transformed practice (NLG, 1996), was more recently reframed as experiencing, conceptualizing, analyzing, and applying by two members of the NLG. They claim that broadening teaching to include these knowledge processes can result in more powerful learning (Cope \& Kalantzis, 2009). In ESL specifically, integrating multimodal projects has the capacity to promote collaboration, learner autonomy, and improve motivation, selfconfidence, and language skills (Ganapathy \& Seetharam, 2016; Kim, 2014; Vinogradova et al., 2011). Angay-Chower et al. (2013) found, too, that "it can develop students' leadership skills as they work as a team, set goals, manage time and resources, and construct a positive identity" (p. 40). My experience also confirms that there is significant value in "letting students create" multimodal presentations.

With reference to ESL teaching, Grapin (2018) makes an important distinction between strong and weak forms of multimodality, whereby weak forms privilege language and use nonlinguistic modes as scaffolds for language development, while strong forms view multiple modes as vital for communicating disciplinary knowledge. With reference to K-12 education, Grapin argues that "the strong form of multimodality is not only necessary but transformative for ELs" (p. 6), particularly in content areas because it demonstrates that semiotic modes are valued, meaning-making tools, and relegating them to secondary significance can perpetuate a deficit view of the resources that English learners (ELs) bring to the classroom. Grapin notes, however, that weak forms are still advocated for language courses, where the goals and objectives are language development. While this may be true, "weak" has negative connotations, especially as creating an effective multimodal presentation requires a strategic combination of language and digital skills; hence, I would refer to this as "targeted" forms of multimodality, while strong forms are more "comprehensive" forms. In other words, in a language course, multimodality is used in a targeted way to support language learning, rather than to develop more comprehensive skills in multiliteracies. Using multimodalities to support language does show that it is valued, and it can promote the development of multiliteracies to some extent. The assessment I use considers both language and the ability to combine modes strategically to communicate (see Appendix A).

\section{Context}

I teach an academic speaking-listening course in an IEP at a university in the American Midwest. Classes meet for 75 min, twice a week, for 15 weeks and range in size from 7 to 20 ESL students. Students have a range of linguistic 
backgrounds, such as Chinese, Arabic, and Hindi, their level of English is intermediate-advanced, and their academic goals cover diverse disciplines.

The overall goal of this course is to help ESL students improve their speaking and listening skills for participation in both formal and informal academic contexts. I am an advocate of community engagement, so I decided to incorporate a service-learning component, which provided a platform for meeting the course goals. Specifically, students prepared face-to-face presentations for residents of a local senior citizens' home, after which they engaged in small group discussions with the seniors. The service-learning project was planned to enable students to demonstrate their language and presentation skills in a different context with an authentic audience. Students could choose to work individually or in pairs, and they could select their own topics (with instructor approval) because allowing choice honoured their preferred learning styles and gave them agency. The service-learning project helped students meet many of the course objectives for speaking-listening, including, for example:

- deliver speeches of specified rhetorical types;

- answer questions in response to a prepared speech;

- raise questions in response to the formal presentation of another;

- demonstrate patterned control of suprasegmental articulation in spontaneous speech;

- produce speech that is intelligible to most native speakers with minimum repetition; and

- use different elicitation devices and registers in conversation.

After the service-learning experience at the seniors' residence, students created a multimodal presentation reflecting what they had learned from the experience. The multimodal reflection was purposefully designed to motivate students and help them develop skills in both language and multimodality. This is what I would characterize as a "targeted form" of multimodality because, while language development was paramount, the other semiotic modes were important for working with language to convey meaning. The final multimodal reflections were presented at the end of semester ESL Symposium, where students throughout the IEP had an opportunity to display their work to each other, to other instructors, and to invited guests.

Students in the speaking-listening course claimed to be positive about the service-learning component, but were less confident about using digital tools, and their skills in using technology varied. As teacher and member of this learning community, I am a "digital immigrant" (Prensky, 2001) and feel confident using only the friendliest of digital tools, such as Google Suite. Throughout the project, however, we all learned from each other and became 
more comfortable with the technology. One student commented that if she had to create the multimodal reflection alone, it would have been difficult, but she worked with a partner, and "it was a smart idea and I thank you actually to give [sic] us the chance."

\section{Procedures}

To help students meet the objectives, the course was divided into four stages. These are described below and a summary is provided in Table 1.

\section{Project Preparation:}

The course started with clear explanations of requirements and expectations for the service-learning project. In the first 3 weeks, I implemented explicit teaching, modelling, and practice activities to equip students with relevant speaking and listening skills, as well as discussion and presentation skills, including PowerPoint design. Explicit instruction in language and presentation skills (delivery and design and integration of visuals) plus opportunities for students to "conceptualize" (Cope \& Kalantzis, 2009) the language and presentation skills were important in helping them prepare for the project.

In Weeks 4 and 5, students prepared and practiced traditional face-to-face presentations. To maintain focus on their speaking skills and lessen anxiety about content knowledge, students chose topics related to their country or culture. The personalized topic made it meaningful and showed them that their identity was valued. Students used the skills they had learned to create PowerPoint slides to enhance their presentation. In Week 6, we conducted peer evaluations of presentations using criteria generated by students with instructor guidance. Feedback from the teacher and peers was given so relevant revisions could be made. Finally, prompts for follow-up discussions were generated and practiced.

\section{Service-Learning Experience:}

In Weeks 7 to 10, students visited a local senior citizens' residence to give their live presentations and engage in small group discussions with the seniors using the prepared prompts. The instructor monitored and took photos (with signed consent). The traditional presentation and interaction with interlocutors not normally encountered during their studies gave students the opportunity to demonstrate language and presentation skills in an authentic context, that is, "to experience the known and the new" (Cope \& Kalantzis, 2009). The seniors served as mentors, and immersion in this meaningful context enabled individuals to draw from and contribute to the community. We conducted weekly debriefings, and students were guided to create audio-recorded reflections in response to set questions. For this, they could use their smartphones, or computers to record. Alternatively, students 
could use platforms, such as https://flipgrid.com/, to video record their reflections, and classmates could give video feedback on their peers' recordings.

\section{Creation of Multimodal Reflections:}

In Weeks 11 to 14, work started on the multimodal reflections. The purpose was for students to reflect on the service-learning experience. They could choose to reflect on what they had learned about a particular senior, on senior living, or on the service-learning experience generally. Multimodality allowed more varied input than speaking alone to illustrate the rich experiences. First, we reviewed the project expectations, discussed what made a strong reflection, and reinforced target language points. Then, we generated ideas on what made a strong multimodal presentation. Importantly, we discussed content, language, visuals, white space, colour, music, and how modes worked together effectively. We discussed how messages could change as combinations of text, visuals, and colours changed. With guidance, students devised a list of criteria to use to evaluate some sample projects. To get started planning the multimodal reflection, I conducted a "think aloud" (Ericsson \& Simon, 1993) to model a reflection. I started by noting things that impacted my learning. I viewed the collection of photos taken during the service-learning experience (posted in Google Drive) and selected those that enhanced my learning points. We also discussed how to find copyrightfree images on https://search.creativecommons.org/ to supplement if needed. Finally, I demonstrated how to use Adobe.Spark to put the presentation together and record the narration. Students could choose to use other platforms if they preferred, but Adobe.Spark is free, relatively simple, and not overwhelming with choices of features. I demonstrated the following steps for students:

1. Sign up for a free spark.adobe.com account.

2. Select + new Adobe video.

3. Choose a template or start from scratch.

4. Add text (limited) and photos (yours or Adobe's).

5. Choose layout (full screen, split screen, caption, title).

6. Record voice and add music (on low) if desired.

7. Check for and remove private/personal or copyrighted information.

8. Add relevant sources and references.

9. Preview. Reorganize and edit if necessary. 
As I demonstrated the features of Adobe.Spark, we discussed how multiple modes communicate meaning together more effectively than one mode alone.

Students then planned their multimodal reflections by preparing an outline of main reflection points and meaningful visuals, which they submitted for grading. To help generate ideas, I encouraged them to revisit their weekly oral reflections. Students could choose to do the outline on paper, or online. There are several online storyboarding sites free to use, such as https://www.canva.com/create/storyboards/, or https://www.storyboardthat. $\mathrm{com} /$. Students then worked on a script for the narration, also submitted for grading. Students practiced their language and arranged the frames to communicate meaningfully. Throughout the preparation, there were opportunities for interaction and teacher and peer reviews. This gave students a chance to learn both language and digital literacy skills from each other, and, based on feedback, revisions could be made to their multimodal reflections. For example, when the narration was unclear due to pronunciation or grammar errors, students could correct the error, practice, and rerecord. When students were unsure how to insert visual transitions, they could get help from a peer.

\section{Performance:}

Finally, in Week 15, the multimodal reflections were completed. Cope and Kalanzis $(2009$, p. 177) claim that "the moment of design is a moment of transformation, of remaking the world by representing the world afresh." Despite the shared experience, students' designs all differed, as seen when they viewed each other's multimodal reflections. They conducted peer assessment using the checklist of previously devised criteria (Appendix B). Viewing the experience through the eyes of others and "analyzing" (Cope \& Kalanzis, 2009) the multimodal reflections helped students to identify areas for improvement and develop their mastery before the reflections were shown to a larger audience at the ESL Symposium.

The creation of the multimodal reflections supported language learning in keeping with Grapin's (2018) "weak" (or my preferred term: targeted) form of multimodality. Final reflections demonstrated that students had learned how to effectively combine visuals, text (oral or written), and space on each frame. For example, titles and captions were strategically designed in terms of colour, font, and placement. Transitions between frames were appropriate, and selected visuals enhanced the communication. In one instance, the narrated text communicated a senior's love of gardening while a photo of the senior's smiling face appeared, to which the student had added a digital sticker in the form of a floral headband.

Transformation, or "application" to creative new contexts (Cope \& Kalanzis, 2009) is not always visible, but students claimed to enjoy the project and liked learning the new skills. One student commented that creating the multimodal project was "very interesting yeah. I never did it before." 
Another talked about how the multimodal format made him more comfortable speaking, "I think this project also made me have [sic] a huge improvement for presentation, I did not feel nervous at all." One student befriended one of the seniors and took the initiative to go back in his own time to visit him and proudly show him his multimodal reflection. Clearly, this was a transformational experience for this student.

Table 1

Stages of Service-Learning Project

\begin{tabular}{|c|c|}
\hline Week & Course Activities \\
\hline $1-5$ & $\begin{array}{l}\text { Instructor gives explanations of requirements and expectations for the service-learning project; } \\
\text { implements explicit teaching, modelling, and practice activities to scaffold development of skills in } \\
\text { speaking, listening, and presentation, including PowerPoint design. }\end{array}$ \\
\hline 6 & $\begin{array}{l}\text { Presentations are practiced and evaluated by peers. } \\
\text { Revisions are made. } \\
\text { Prompts for discussion topics are generated. }\end{array}$ \\
\hline $7-10$ & $\begin{array}{l}\text { Service-learning experience: students visit seniors' residence; deliver live presentations and engage } \\
\text { in small group discussions with seniors. Instructor takes photos (with signed consent). } \\
\text { Weekly debriefings are conducted. } \\
\text { Students record oral reflections based on instructions and examples. }\end{array}$ \\
\hline $11-14$ & $\begin{array}{l}\text { Class reviews guidelines for multimodal reflection and discusses multimodality. } \\
\text { Instructor explains and demonstrates use of Adobe.Spark. Students prepare outline, images, and } \\
\text { draft scripts. Peer interaction and review occurs at various stages. Revisions are made based on } \\
\text { feedback. }\end{array}$ \\
\hline 15 & Final multimodal reflections are completed and shared in class and at ESL Symposium. \\
\hline
\end{tabular}

Assessment

Significant skill development activities were implemented in advance of the service-learning project and the project itself was broken down into manageable stages that incorporated both traditional and digital tools. Work done in each stage was assessed to communicate the importance of all stages (see Table 2).

Table 2

Project Requirements

Outline (digital or written), draft scripts and visuals for live presentation (Weeks 3-6), and

multimodal reflection (Weeks 11-14), contributions to weekly class debriefings (weeks 7-10),

$10 \%$

two individual recorded reflections (1-2 min; Week 8 and 10)

10-min live presentation on home country/culture (Week 6) 10\%

2-3-min multimodal reflection presentation on what was learned in the service-learning experience (Week 15) 
A rubric for assessing the multimodal presentation is provided in Appendix A, along with a checklist for self and peer review (Appendix B).

\section{Reflection on Effectiveness: Benefits, Challenges, Issues}

Implementing both traditional and multimodal presentations in a speakinglistening course enabled students to practice and demonstrate their language skills and digital literacy in multiple contexts - formal and informal, live and recorded. As such, students' different learning preferences could all be satisfied. Including a multimodal reflection had further benefits. Similar to the research cited earlier, the most salient aspect for my students was increased motivation. The choices and freedom to be creative using digital tools likely contributed to this motivation, but other factors included experiencing an alternative to traditional presentations, increased peer teaching opportunities, the chance to rerecord the presentation, and the fact that the multimodal reflection was shared to broader audiences. The more public "performance" of the multimodal reflection led most students to put forth extra effort to polish their language and pronunciation, as well as arrange visuals, text, and other modes effectively. Indeed, many students rerecorded their narration multiple times to meet their own high standards. This demonstrated their metacognitive skills as they were able to identify their strengths and weaknesses. The repetition of language also helped them improve their pronunciation and confidence in speaking. It also cultivated a sense of pride in their finished project as evidenced by the fact that several students shared their reflections with friends and family back home.

There were challenges in implementing digital tools, and some were easier than others to address. First, students' and teacher's experience with technology varied, and, even if individuals were competent using technology, they were not necessarily digitally literate, that is, able to locate, consume, create, and communicate digital information (Spires \& Bartlett, 2012). To address this, I had my students study example slides and explain how the text message changed when visuals, colours, font sizes, and spaces changed. I allowed students to choose the tools they felt most comfortable with. Explicitly teaching and modelling tools helped, and, importantly, peers taught each other-and their instructor-how to use other digital tools and features. In this way, "the instructor and students jointly fostered a learning community in which they collectively co-constructed knowledge" (Yi \& Angay-Crowder, 2016, p. 996). Providing opportunities for project work in class often resulted in students willingly helping each other to enhance existing, and acquire new, digital skills. Even those who did the project individually typically worked collaboratively in class on learning the digital skills. Importantly, in helping 
each other with these technical aspects, students used their English skills to communicate with purpose in an authentic context.

Another challenge that arose was students focusing too much on the technology to the detriment of language, that is, they tended to rely on overly simplistic vocabulary and language structures, and, often when students from the same country paired up, it was tempting for them to depend on their first language (L1) in their project discourse. To address this, I conducted short mini lessons on target language structures and provided sentence frames if needed. I monitored pairs to make sure L1 was used as a resource, not as the sole language of communication. And I taught students to self-monitor and conduct peer assessments at various stages of development.

In other contexts, students may feel a sense of urgency in developing their language skills and place less value on digital skills. Teachers, too, may feel constrained by curriculum requirements that do not account for multimodality. It is up to the teacher to explain the importance of developing digital literacy to both the students and curriculum developers.

Related to this, assessment can be challenging. Prensky (2010, p. 153) warns that "teachers need to be careful not to praise or evaluate work too highly just because it uses technology." I found that making expectations clear, creating transparent rubrics that assess both language and digital skills (see Appendix A), and giving students opportunities to use them for self- and peer-assessment helped. Some teachers also worry about freeloaders or lack of motivation by some students. I did not find this to be a problem but if it is, Prensky (2010) offers this advice: Find out what the students like, give choices, provide opportunities for interaction so the motivated students can "pull the others along," and arrange for real-world audiences to view the final projects.

\section{Adaptations}

Instructors can adapt this project for any level from K-12 to adult by adjusting the amount of focus and level of explicit teaching on multimodalities, and by modifying the amount of scaffolding and teacher oversight for the context. More experienced digital learners can learn more autonomously and use more sophisticated software, like iMovie, while less experienced digital learners can be guided with more joint class constructions, controlled practice, and fixed templates, like writereader.com.

If service-learning is not possible, other experiential activities can be substituted, like field trips, peer-to-peer reading, nature walks, (playground) gardening, guest speakers, and so forth. Subsequent multimodal reflections would demonstrate what students learned from the experience. 


\section{Conclusion}

Broadening the traditional ESL speaking-listening courses to include both live and multimodal presentations has many benefits. The use of multimodal reflections on a service-learning experience can enhance both literacy development and multimodal learning of ESL learners. Such a project strongly advocates the importance of generating real conversations and offering comprehensible input for ESL learners, motivating them to bring their prior experience and personal voices to their learning, and creating a project via multimodal practices to show pride and ownership of their work. Students are motivated when teachers build a collaborative learning environment through explicit teaching, allowing choices, providing opportunities for peer interaction, and freedom to create. In addition, intentionally teaching how oral texts and semiotic modes work together purposefully to express meaning more effectively than a single mode alone can show ESL students that both language and multimodality are valued. Skills in both language and multimodality can develop through "experiencing" language and multimodality in both traditional and new, authentic contexts, "conceptualizing" through explicit teaching, scaffolding, and practice opportunities, "analyzing" through peer interactions, and "applying" in performance settings and beyond.

\section{The Author}

Cynthia J. Macknish has an EdD in Teaching English to Speakers of Other Language (TESOL) and Applied Linguistics and has experience teaching various levels in Canada, the Bahamas, China, and Singapore. Currently, she enjoys teaching ESL and TESOL at Eastern Michigan University.

\section{References}

Angay-Crowder, T., Choi, J., \& Yi, Y. (2013). Putting multiliteracies into practice: Digital storytelling for multilingual adolescents in a summer program. TESL Canada Journal, 30(2), 36-43. https://doi.org/10.18806/tesl.v30i2.1140

Cope, W., \& Kalantzis, M. (2009). Multiliteracies: New literacies, new learning. Pedagogies: An International Journal, 4, 164-195. https://doi.org/10.1080/15544800903076044

Ericsson, K. A., \& Simon, H. A. (1993). Protocol analysis: Verbal reports as data (Revised edition). Cambridge, MA: MIT Press.

Ganapathy, M., \& Seetharam, S. (2016). The effects of using multimodal approaches in meaningmaking of 21st century literacy texts among ESL students in a private school in Malaysia. Advances in Language and Literary Studies, 7(2), 143-155. http://dx.doi.org/10.7575/aiac. alls.v.7n.2p.143

Grapin, S. (2018). Multimodality in the new content standards era: Implications for English learners. TESOL Quarterly, 53(1), 1-26. doi: 10.1002/tesq.443

Kim, S. H. (2014). Developing autonomous learning for oral proficiency using digital storytelling. Language Learning \& Technology, 18(2), 20-35. Retrieved from http://lt.msu.edu/issues/ june2014/action1.pdf

New London Group. (1996). A pedagogy of multiliteracies: Designing social futures. Harvard Educational Review, 66(1), 60-92. Retrieved from https://www.academia.edu/2804125/A_pedagogy_of_multiliteracies_Designing_social_futures 
Prensky, M. R. (2001). Digital natives, digital immigrants, Part 1. On the Horizon, 9(5), 1-6. https:// doi.org/10.1108/10748120110424816

Prensky, M. R. (2010). Teaching digital natives: Partnering for real learning. Thousand Oaks, CA: Corwin.

Ryan, M. (2012). Service-learning after Learn and Serve America: How five states are moving forward. Denver: Education Commission of the States. Retrieved from https://www.ecs.org/clearinghouse/01/02/87/10287.pdf

Spires, H. A., \& Bartlett, M. E. (2012). Digital literacies and learning: Designing a path forward. Friday Institute White Papers. North Carolina State University. Retrieved from https://www.fi.ncsu. edu/wp-content/uploads/2013/05/digital-literacies-and-learning.pdf

Vinogradova, P., Linnville, H., \& Bickel, B. (2011). Listen to my story and you will know me: Digital stories as student-centered collaborative projects. TESOL Journal, 2(2), 173-202. https://doi.org/10.5054/tj.2011.250380

Yi, Y., \& Angay-Crowder, T. (2016). Multimodal pedagogies for teacher education in TESOL. TESOL Quarterly, 50(4), 988-998. https://doi.org/10.1002/tesq.326

\section{Appendix A}

\section{Rubric for Multimodal Reflections}

\begin{tabular}{ll}
\hline Score & Criteria \\
\hline Well above expectations & Clear \& insightful content; appropriate rhetorical features \\
& Credible claims supported with useful, relevant examples \\
& Information organized coherently; smooth transitions \\
& Intelligible speech; effective control of suprasegmental features (rhythm, \\
& intonation, volume, etc.) \\
& Wide range of vocabulary \& grammatical structures \\
& Strategic selection of visuals \\
& Modes work together very effectively \\
& Viewer interest stimulated throughout \\
\hline Above Expectations & Clear content; appropriate rhetorical features \\
& Appropriate claims supported with relevant examples \\
& Information organized coherently; smooth transitions \\
& Intelligible speech; control of suprasegmental features (rhythm, intonation, \\
& volume, etc.) \\
& Range of vocabulary \& grammatical structures \\
& Good selection of visuals \\
& Modes work together effectively \\
& Viewer interest maintained throughout \\
\hline & Generally clear content; appropriate rhetorical features \\
& Claims supported with examples \\
Information generally organized coherently; fairly smooth transitions \\
Generally intelligible speech; some control of suprasegmental features \\
(rhythm, intonation, volume, etc.) \\
Dependence on simple vocabulary \& grammatical structures \\
Fairly good selection of visuals \\
Modes work together fairly well \\
Viewer interest generally maintained \\
\hline Meets Expectations
\end{tabular}




\begin{tabular}{ll}
\hline Score & Criteria \\
\hline Approaching Expectations & Content and/or rhetorical features may need clarity or elaboration \\
& Claims may not be supported \\
& Organization may need work \\
& Speech may be frequently unintelligible \\
& Overly simple or flawed vocabulary \& grammatical structures \\
& Weak selection of visuals \\
& Modes don't work together well \\
\hline
\end{tabular}

\section{Appendix B}

\section{Self/Peer Assessment of Multimodal Presentation}

\begin{tabular}{l}
\hline Checklist for multimodal presentation \\
\hline Does the reflection describe what was learned? \\
Name one learning point you observed/heard: \\
\hline Do examples support the claims? \\
Write one example you observed/heard: \\
\hline Is the narration understandable? \\
If not, why not? \\
\hline Do the photos enhance the information? \\
Explain one example: \\
\hline Do the modes work well together? \\
Give an effective example: \\
How could they be improved? \\
\hline Are the transitions smooth? \\
Explain: \\
\hline Is there a range of vocabulary and grammatical structures? \\
Note examples: \\
\hline Is the presentation interesting? \\
Why/why not?
\end{tabular}

